\title{
PENGOLAHAN CITRA DAN METODE SUPPORT VECTOR MACHINE (SVM) DALAM PENGENALAN POLA TANDA TANGAN
}

\author{
Rahmat Pujianto $^{1}$, Mei Lestari ${ }^{2}$, Ni Wayan Parwati Septiani ${ }^{3}$ \\ ${ }^{123}$ Program Studi Teknik Informatika, Fakultas Teknik dan Ilmu Komputer \\ Universitas Indraprasta PGRI \\ Jalan Raya Tengah No 80, Kelurahan Gedong, Pasar Rebo, Jakarta Timur \\ rahmat.cwe@gmail.com¹, mei.lestari6@gmail.com², wayan.parwati@gmail.com³
}

\begin{abstract}
Abstrak
Tanda tangan atau paraf merupakan tulisan tangan dengan gaya tulisan tertentu dari nama seseorang dan merupakan identifikasi yang ditulis pada dokumen sebagai bukti identitas. Masalah yang akan dibahas pada penelitian ini adalah sulitnya mengidentifikasi pemalsuan tanda tangan pada pengesahan skripsi. Artikel ini mengusulkan model identifikasi tanda tangan yang mengaplikasikan pengolahan citra dengan ekstraksi ciri menggunakan Gabor Filters, Hue Saturation Value (HSV), Gray Level Co-occurance (GLCM) dan klasifikasi Support Vector Machine (SVM). Terdapat 300 citra tanda tangan yang dibagi menjadi data latih dan data uji, kemudian citra akan diekstraksi menggunakan Filter Gabor, HSV dan GLCM, kemudian akan diklasifikasikan menggunakan metode klasifikasi SVM untuk diklasifikasikan citra data latih yang sesuai. Akurasi model identifikasi tanda tangan berdasarkan perhitungan Confusion Matrix adalah 94,3\%.
\end{abstract}

Kata Kunci: Tanda Tangan, Filter Gabor, HSV, GLCM, Support Vector Machine (SVM)

\begin{abstract}
Handwritten signature is a handwritten with certain writing style of someone initial or name. it is utilized as a method for individual distinguishing proof apparatus. We address the problem on difficulty on identifying signature originality on thesis validity sheet. This paper, proposed a signature identification model that applies image processing with feature extraction using Gabor Filters, Hue Saturation Value (HSV), Gray Level Cooccurrence Matrix (GLCM) and Support Vector Machine (SVM) classification method. There are 300 signature images split into training data and testing data, then images will be extracted using Gabor Filters, HSV and GLCM, then it will be classified using SVM classification methods to be classified with match training data image. Accuracy on identification signature model based on confusion Matrix calculation is $94,3 \%$.
\end{abstract}

Keyword: Signature, Gabor Filters, HSV, GLCM, Support Vector Machine (SVM)

\section{PENDAHULUAN}

Tanda tangan atau paraf merupakan tulisan tangan dengan gaya tulisan tertentu dari nama seseorang dan merupakan identifikasi yang ditulis pada dokumen sebagai bukti identitas. Pentingnya tanda tangan khususnya sebagai bukti pengesahan terkadang disalah gunakan. Manusia dapat dengan mudah memalsukan tangan yang berdampak merugikan orang lain/pihak terkait lainnya.

Teknologi identifikasi pengenalan pola tanda tangan termasuk dalam biometrika yang menggunakan karakteristik prilaku alami manusia. Secara umum, untuk mengidentifikasi tanda tangan dapat dilakukan dengan cara menual yaitu dengan cara menyocokkan tanda tangan pada saat transaksi. Sistem manual memiliki kelemahan dimana pemeriksa tanda tangan kurang teliti dalam melakukan pencocokkan. Oleh karena itu diperlukan sebuah metode yang mampu menganalisis karakteristik tanda tangan sehingga mempermudah dalam mengenali tanda tangan seseorang.

Digital Image Processing atau pengolahan citra digital menurut Gonzalez adalah proses pengambilan atribut-atribut pada gambar dengan input dan output berupa gambar. Operasi pada citra digital antara lain, penajaman gambar, pengidentifikasian gambar, pengurangan noise, konversi warna ke greyscale atau sebaliknya, kompresi data pada gambar dan lain sebagainya [1]. 
Djamal, dkk menggunakan multilayer perceptron dalam mengenali pola tanda tangan, hasil identifikasi dari 100 tanda tangan menghasilkan akurasi sebesar $87 \%$ untuk mengenali tepi ekstrim, struktur titik, tanda tangan terpisah, coretan garis terputus yang menggunakan metode indentifikasi struktur. Sedangkan identifikasi awal kurva, coretan akhir, cangkang, coretan tengah dan garis bawah menggunakan multilayer perceptron didapat akurasi sebesar 56-75\%[2].

Sedangkan Damayanti dan Setiawan melakukan pengenalan tanda tangan menggunakan metode Modified Direction Feature (MDF) dan Euclidian Distance, penggunaan MDF akan menghasilkan vector ciri dengan pedoman arah horizontal dan vertical, kemudian dilakukan penggabungan untuk menghasilkan vector ciri yang spesifik dan selanjutnya dilakukan perhitungan klasifikasi dengan menggunakan Euclidian Distance. Hasil akurasi yang didapat adalah 72\% dengan menggunakan 100 citra sebagai data latih, dan 25 citra sebagai data uji [3].

Filter Gabor merupakan salah satu filter yang mampu mensimulasikan karakteristik sistem visual manusia dalam mengisolasi frekuensi dan orientasi tertentu dari citra [4]. Secara spasial, sebuah fungsi Gabor merupakan sinusoida yang dimodulasi oleh fungsi Gauss.

Hue merupakan warna yang dikenal manusia seperti merah dan hijau,warna yang ditangkap oleh mata manusia berdasarkan Panjang gelombang yang dihasilkan. Saturation merupakan level kemurnian warna atau banyaknya cahaya putih yang tercampur dengan hue. Setiap warna murni memiliki nilai saturasi $100 \%$. Value menyatakan intensitas pantulan dari objek yang diterima mata, dinyatakan sebagai perubahan warna putih menuju abu-abu dan terakhir mencapai warna hitam, atau yang dikenal dengan istilah aras keabuan atau greyscale.

Sedangkan Gray Level Cooccurrence Matrix (GLCM) merupakan metode yang digunakan untuk ekstrasi ciri. Pendekatan GLCM bekerja dengan membentuk sebuat matriks kookurensi data citra, dilanjutkan dengan menentukan ciri sebagai fungsi dari matriks antara tersebut. Kookurensi yaitu jumlah kejadian satu level nilai piksel bertetangga dengan satu level nilai piksel lain dalam jarak (d) dan orientasi sudut $(\theta)$ tertentu. Jarak dinyatakan dalam piksel dan orientasi dinyatakan dalam derajat. Orientasi dibentuk dalam 4 arah sudut dengan interval sudul $45^{\circ}$, yaitu $0,45,90$ dan 135 derajat [5].

Berdasarkan uraian di atas maka penelitian ini bertujuan untuk mendeteksi atau mengenali tanda tangan menggunakan pengolahan citra dan metode klasifikasi Support Vector Machine (SVM).

\section{METODE PENELITIAN}

Penelitian ini menggunakan studi Pustaka sebagai tahap awal, mempelajari landasan teori mengenali identifikasi pola tanda tangan, pengolahan citra digital dan metode klasifikasi SVM. Landasan teori diambil dari jurnal, e-book, internet dan buku terkait dengan penelitian ini.

Penulis menjabarkan prosedur identifikasi atau mengenali pola tanda tangan menggunakan Filter Gabor, Hue Saturation Value (HSV), Gray Level Co-Occurrence Matrix (GLCM) dan metode klasifikasi SVM. Penerapan sistem akan dilakukan untuk mengenali tanda tangan pada lembar pengesahan skripsi. Data citra yang digunakan merupaka 30 tanda tangan pembimbing, dan masingmasing pembimbing memberikan contoh 10 data citra tanda tangan.

Gambar berikut merupakan gambar perancangan model sistem identifikasi tanda tangan 


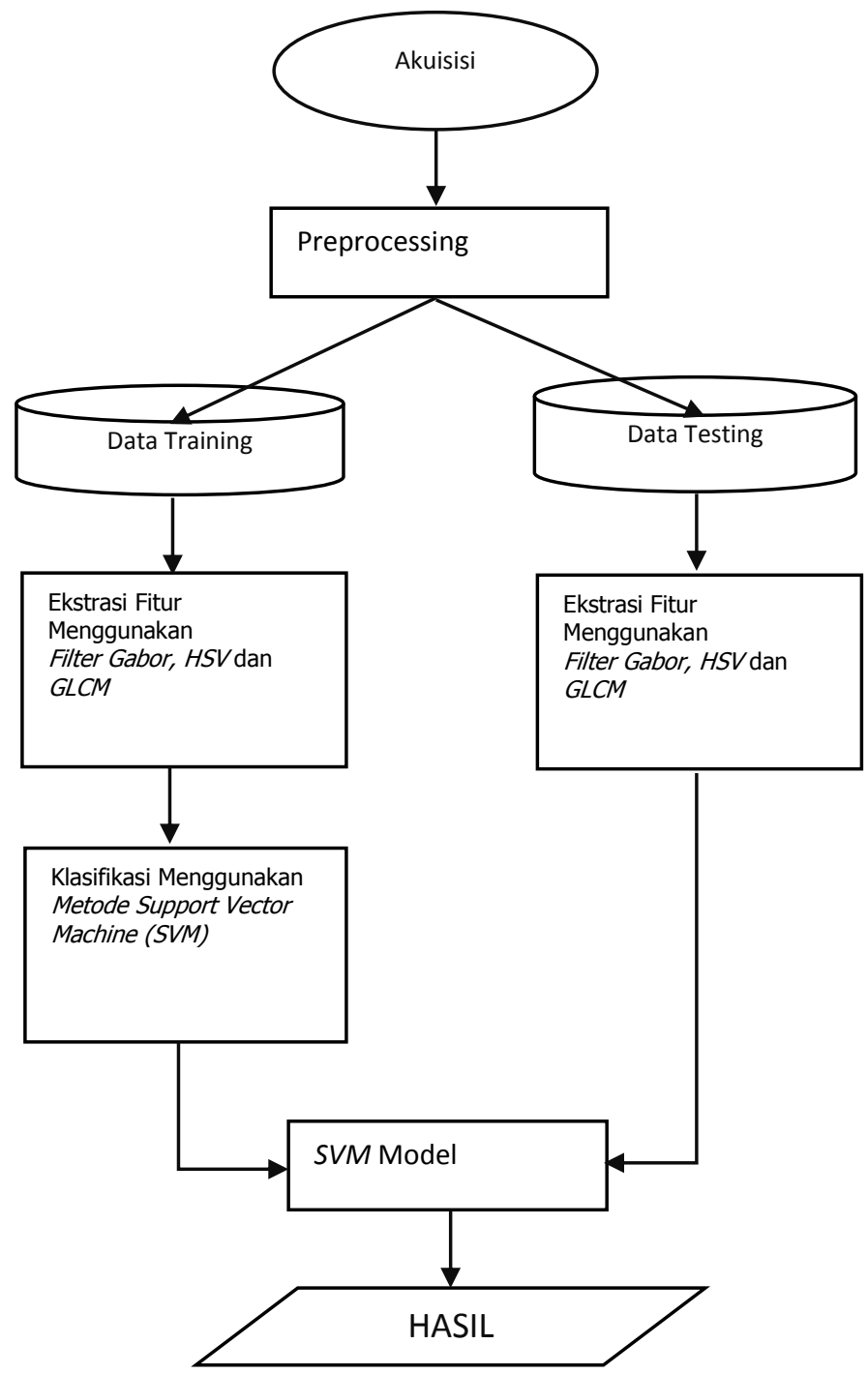

Gambar 1. Rancangan model identifikasi tanda tangan

\section{HASIL DAN PEMBAHASAN}

\section{Akuisisi}

Peneltian ini menggunakan non-random sampling, dimana semua tanda tangan memiliki kesempatan untuk dipilih. Tanda tangan diambil dari lembar pengesahan siding skripsi, foto tanda tangan dilakukan secara manual menggunakan kamera telepon genggam, untuk 30 dosen pembimbing pada semester genap 2018 pada suatu program studi Universitas XYZ. Masing- masing pembimbing memberikan 10 sample tanda tangan, sehingga total terdapat 300 tanda tangan yang digunakan sebagai data latih (training data).

\section{Preprocessing}

Pada tahapan ini dilakukan proses penghilangan noise dan memperbaiki hasil segmentasi citra, dapat dilihat pada gambar berikut: 


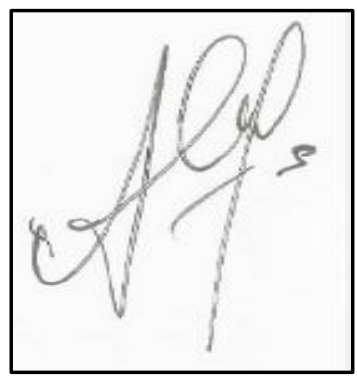

Sebelum preprocessing

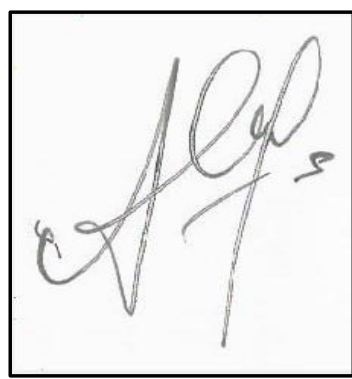

Sesudah preprocessing

Gambar 2. Citra setelah preprocessing

\section{Penentuan Data Latih dan Data Uji}

Data latih merupakan data yang digunakan sebagai parameter, digunakan untuk melatih algoritma. Data uji merupakan data yang digunakan untuk mengetahui performa suatu algoritma. Pada tahapan ini data akan dibagi menjadi 2 jenis data, yaitu data latih (training data) dan data uji (testing data). Data latih yang digunakan adalah $70 \%$ dari keseluruhan data, yaitu 210 citra tanda tangan, sedangkan data uji yang digunakan adalah 30\% dari keseluruhan data, yaitu 90 citra tanda tangan.

Tabel 1. Contoh tanda tangan sebagai data latih dan data uji

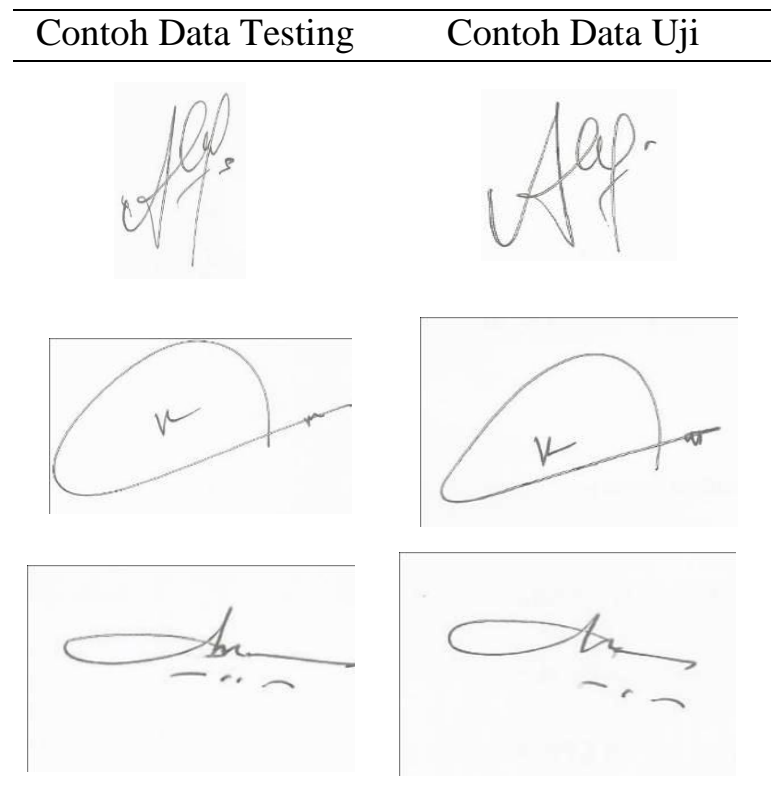

\section{Ekstrasi Ciri Menggunakan Filter Gabor, HSV dan GLCM}

Kegunaan dari ektraksi Filter Gabor ini mampu mensimulasikan karakteristik sistem visual manusia, bertujuan pengenalan tekstur dalam bidang Computer Vision. Kegunaan dari GLCM merupakan ekstraksi ciri statistik orde kedua dengan memakai matriks kookurensi, yaitu suatu matriks antara yang merepresentasikan hubungan ketetanggaan antar piksel dalam citra pada berbagai arah orientasi dan jarak spasial. Salah satu teknik untuk memperoleh ciri statistik orde dua adalah dengan menghitung probabilitas hubungan ketetanggaan antara dua piksel pada jarak dan orientasi sudut tertentu. Pendekatan ini bekerja dalam dua tahapan, yaitu: pembentukan sebuah matriks kookurensi dari data citra, dilanjutkan dengan penghitungan ciri sebagai fungsi dari matriks. Kegunaan dari $H S V$ untuk 
membedakan suatu objek dengan warna tertentu dapat menggunakan nilai hue yang merupakan representasi dari cahaya tampak (merah, jingga, kuning, hijau, biru, ungu). Nilai hue dapat dikombinasikan dengan nilai saturation dan value yang merupakan tingkat kecerahan suatu warna. Untuk mendapatkan ketiga nilai tersebut, perlu dilakukan konversi ruang warna citra yang semula RGB (Red, Green, Blue) menjadi HSV (Hue, Saturation, Value).

Pada tahapan ekstraksi Filter Gabor dilakukan pengenalan berdasarkan tekstur orientasi dan mengisolasi frekuensi (Mean, Ent dan Var). Filter Gabor merupakan teknik ekstraksi ciri dengan mengambil informasi penting dari sudut orientasi dan frekuensi spasial, dapat dilihat pada gambar berikut:

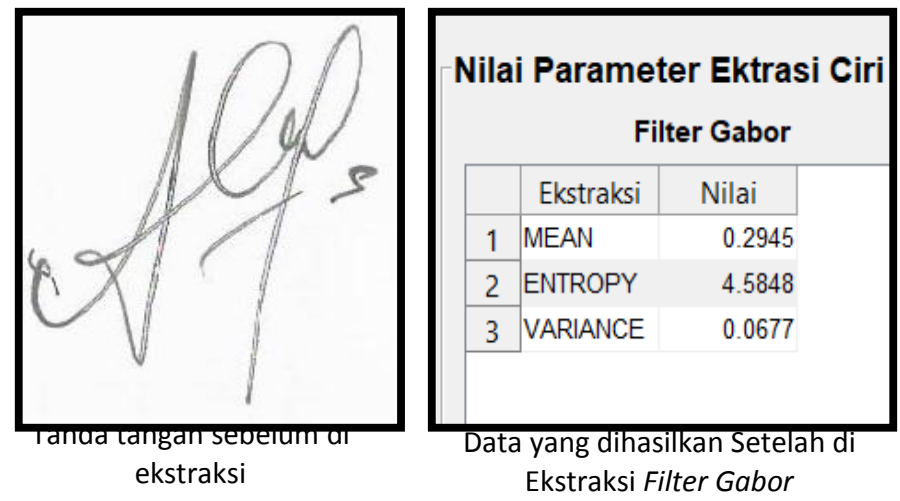

Gambar 3. Hasil Ekstraksi Filter Gabor

Terdapat beberapa langkah yang harus dilakukan pada ekstraksi GLCM, yaitu mengubah citra menjadi berskala keabuan; menciptakan matrik co-occurrence; menentukan hubungan spasial antara piksel referensi dengan piksel tetangga; menentukan matrik simetris dengan menambahkan matrik coooccurence dengan matrik transpose-nya; melakukan normalisasi terhadap matrik simetris dengan menghitung probabilitas setiap elemen matrik.

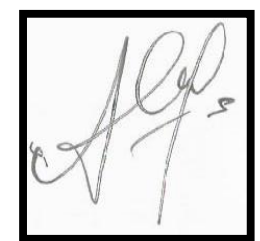

Sebelum di ekstraksi

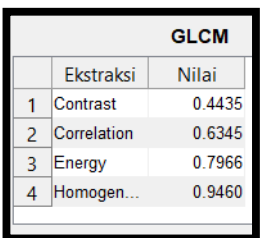

Setelah di ekstraksi GLCM

Gambar Error! No text of specified style in document.. Hasil Ekstraksi GLCM

Terakhir, tahapan ekstrasi HSV dilakukan dengan perhitungan Hue, Saturation dan Value. Contoh hasil ekstrasi dapat dilihat pada gambar berikut:

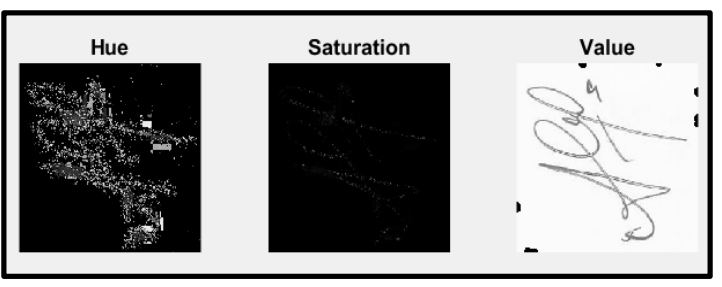

Gambar 5. Hasil Ektraksi HSV 


\section{Klasifikasi Support Vector Machine (SVM)}

Pada tahapan klasifikasi SVM menampilkan hasil identifikasi berdasarkan data yang dihasilkan oleh penerapan ekstraksi ciri dan tekstur. Citra tanda tangan yang sudah diekstraksi menggunakan tiga metode di atas akan diklasifikasikan menggunakan metode SVM untuk diklasifikasikan dalam kelas citra tanda tangan. Jika tanda tangan sesuai maka nama dosen pembimbing yang sesuai akan tampil sebagai hasil.

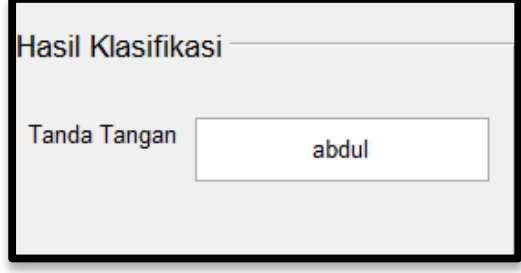

Gambar 6. Tampilan Hasil Proses Klasifikasi SVM

\section{Tampilan Awal Model Identifikasi Tanda Tangan}

Tampilan layar model identifikasi tanda tangan dosen pembimbing skripsi dapat dilihat pada gambar berikut:

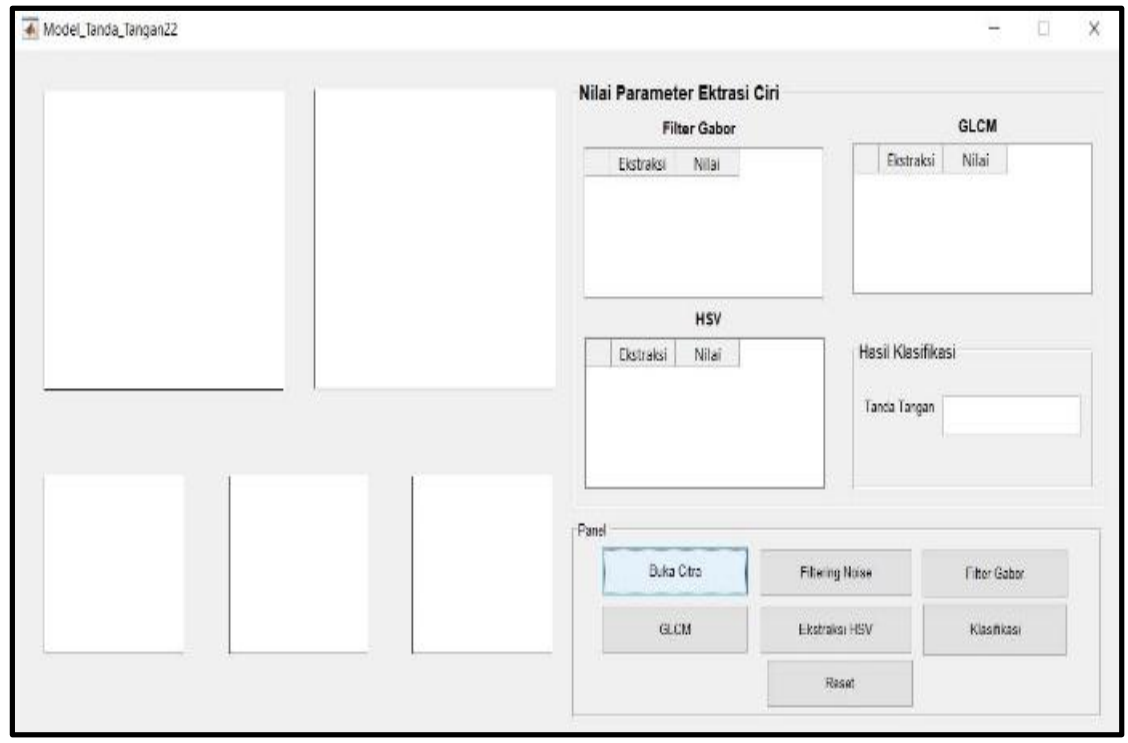

Gambar 7. Tampilan Layar Model Identifikasi Tanda Tangan

Pada tampilan layar di atas terdapat 6 jenis opsi, yaitu opsi tombol "Buka Citra", "Filtering Noise", "Filter Gabor", "GLCM", "Ekstraksi HSV", "Klasifikasi" dan "Reset". Tanda tangan yang akan diidentifikasi dapat dipilih dengan memilih tombol "Buka Citra", kemudian selanjutnya pilih tombol "Filtering Noise", kemudian secara berurut pilih tombol "Filter Gabor", "GLCM", dan "Ekstraksi HSV", terakhir pilih tombol "Klasifikasi SVM". Tombol "Reset" digunakan untuk menguji citra lain setelah dilakukan pengujin sebelumnya. 


\section{Pengujian Menggunakan Confusion Matrix Multi Class}

Model identifikasi tanda tangan berdasarkan tekstur dan bentuk pola tanda tangan telah dilakukan pengujian menggunakan Confusion Matrix Multi Class didapatkan rata-rata tingkat akurasi sebesar99,43\%.

\section{SIMPULAN}

Berdasarkan hasil analisis dan uraian di atas maka dapat ditarik kesimpulan yaitu, identifikasi tanda tangan menggunakan cir Filter Gabor, HSV, GLCM dan metode klasifikasi SVM terhadap 300 citra tanda tangan dari 30 pembimbing skripsi, menghasilkan akurasi sebesar 99,43\%. Terjadinya kesalahan dalam mengenali atau identifikasi tanda tangan disebabkan karena adanya kemiripan tanda tangan yang satu dengan lainnya. Untuk mengetahui metode terbaik untuk mengidentifikasi tanda tangan, maka diperlukan penelitian lanjutan dengan metode pengolahan citra dan klasifikasi yang berbeda.

\section{DAFTAR PUSTAKA}

[1] R. C. Gonzalez, R. E. Woods, and S. L. Eddins, "Digital Image Processing Using Matlab - Gonzalez Woods \& Eddins.pdf," Education. 2004.

[2] E. C. Djamal and S. N. Ramdlan, "Pengenalan Pola Tanda Tangan Menggunakan Multilayer Perceptron dalam Identifikasi Kepribadian,” Semin. Nas. Sist. Inf. Indones., 2013.

[3] F. Damayanti and W. Setiawan, "Pengenalan Tanda Tangan Dengan Metode Modified Direction Feature ( Mdf ) Dan Euclidean Distance," Pros. Conf. Smart-Green Technol. Electr. Inf. Syst., 2013.

[4] J. DAUGMAN, "Gabor Wavelets and Statistical Pattern Recognition," Handb. Brain Theory Neural Networks, 2003.

[5] A. A. Kasim, R. Wardoyo, and A. Harjoko, "Batik classification with artificial neural network based ontexture-shape feature of main ornament," Int. J. Intell. Syst. Appl., 2017. 